\title{
Pituitary and ovarian response to transient doe-litter separation in nursing rabbits
}

\author{
E. Ubilla ${ }^{1}$, P. G. Rebollar ${ }^{1}$, D. Pazo ${ }^{2}$, A. I. Esquifino ${ }^{2}$ and J. M. R. Alvariño ${ }^{1}$ \\ ${ }^{1}$ Departamento de Producción Animal, ETSI Agrónomos, Universidad Politécnica, Ciudad Universitaria s/n, 28040 Madrid, Spain; \\ ${ }^{2}$ Departamento de Bioquímica, Facultad de Medicina, Universidad Complutense, Ciudad Universitaria s/n, 28040 Madrid, Spain
}

\begin{abstract}
The effects of a transient doe-litter separation on plasma prolactin, FSH and oestradiol concentrations, as well as the effect on LH response to exogenous $\mathrm{GnRH}$ administered at the time of artificial insemination, were determined in nursing rabbits. The effects on fertility, and litter size after parturition, as well as litter survival after doe-litter separation, were also studied. Control does $(n=12)$ had free access to nursing, whereas biostimulated does $(n=12)$ were separated from their litters for $48 \mathrm{~h}$ before artificial insemination. Plasma prolactin concentrations were decreased $24 \mathrm{~h}$ after the doe-litter separation $(P<0.05)$. The response of prolactin to suckling reached 10 times the basal values measured on day 10 after parturition $(P<0.0001)$. Increased oestradiol concentrations were found during the $48 \mathrm{~h}$ after the doe-litter separation: at $0 \mathrm{~h}$, before artificial insemination $(P<0.0001), 1.0-2.0 \mathrm{~h}$ after artificial insemination $(P<0.001)$, at $2.5 \mathrm{~h}(P<0.05), 3.0 \mathrm{~h}(P<0.01)$, and at $3.5 \mathrm{~h}(P<0.05)$ after artificial insemination. Exogenous GnRH administered at the time of artificial insemination caused a greater $\mathrm{LH}$ response in does previously separated from their litters during $48 \mathrm{~h}(P<0.01)$. The transient doe-litter separation did not affect plasma FSH concentrations, fertility, litter size or litter survival. These results suggest that a transient separation of nursing does from their litters before artificial insemination results in a decrease in plasma prolactin concentrations that could promote growth of follicular waves, and high steroidogenesis activity, leading to increased oestradiol concentrations and inducing higher sensitivity of the pituitary gland to exogenous GnRH. These findings associated to the absence of suckling episodes would lead to higher LH response and , therefore, exert a major effect on fertility.
\end{abstract}

\section{Introduction}

In nursing rabbits, the sexual receptivity and fertility obtained after artificial insemination appear to be depressed during the period of lactation, through a hormonal antagonism between prolactin and release of gonadotrophins (Theau-Clément and Roustan, 1992; Fortun and Bolet, 1995; Ubilla and Rebollar, 1995). In addition, high prolactin concentrations could inhibit the ovulatory process (Lin et al., 1987) and thus affect the rupture of mature Graafian follicles (Yoshimura et al., 1990). Nursing rabbits that accept mating showed higher fertility and litter size compared with nonreceptive rabbits (Rebollar et al., 1992). In rabbits, it has been established that mating is directly related to the turgidity and colour of the vulva (Rodriguez et al., 1989). Three sexual receptivity levels have been described: does with red or pink turgid vulvas have $92 \%$ mating acceptance (high sexual receptivity), does with pink non-turgid or purple turgid vulvas have $55 \%$ mating acceptance (medium sexual receptivity), and does with purple, non-turgid, or pale vulvas have $24 \%$ mating acceptance (low sexual receptivity)

Received 3 August 1999.
(Rodriguez et al., 1989). Higher ovulation responses are obtained in rabbits showing high or medium sexual receptivity after i.m. injection of $20 \mu \mathrm{g}$ or $40 \mu \mathrm{g} \mathrm{GnRH}$ (Rodriguez and Ubilla, 1988), with a clear LH dose-response to GnRH in medium and high sexual receptivity lactating rabbits (Rodriguez et al., 1989). Highest LH and FSH concentrations are reached 60-90 min after exogenous administration of $\mathrm{GnRH}$, decreasing to basal concentrations 4-5 h later (Mills and Gerardot, 1984; Rodriguez et al., 1989; Rebollar et al., 1997).

Mean plasma concentrations of oestradiol showed two increments, one during the first days and a second increment during the last week (day 24-30), in high sexual receptivity does; in contrast medium or low sexual receptivity lactating rabbits did not follow this pattern during lactation (Ubilla and Rebollar, 1995). High plasma concentrations of prolactin associated with low plasma oestradiol and sexual receptivity are observed from days 7 to day 24 of lactation (Ubilla et al., 1992; Ubilla and Rebollar, 1995). All of these changes induce an irregular alternation of oestrus and anoestrus in rabbits which make it difficult to establish a synchronized reproduction rhythm using artificial insemination (Maertens, 1998). 
Several methods for the synchronization of oestrus have been proposed to improve fertility in nursing rabbits: these include systematic stimulation of ovarian activity with gonadotrophins (Colin, 1992), or administration of $\mathrm{PGF}_{2 \alpha}$ (Dragan et al.,1996; Pimienta et al., 1996). More recently, several alternative methods to hormonal treatments based on a controlled lactation (the so-called biostimulation methods) have been developed to stimulate the sexual receptivity and fertility in rabbits. Separation of does from litters for short periods before artificial insemination resulted in higher sexual receptivity and fertility (Pavois et al., 1994; Alvariño et al., 1998; Castellini et al., 1998; Maertens, 1998). In addition, changes in the environment of the rabbit account for higher sexual receptivity and fertility (Luzi and Crimella, 1998). After biostimulation, fertility reached similar values to those obtained after administering PMSG before artificial insemination (Facchin et al., 1992; Pavois et al., 1994). These stimuli probably promote sexual receptivity, and increase fertility through changes in the activities of the hypothalamus-pituitary-ovarian axis (Castellini et al., 1998). Nevertheless, the endocrine mechanisms involved in these events are not fully understood.

Thus, the aim of this study was to investigate the effects of a transient doe-litter separation on plasma prolactin, FSH and oestradiol concentrations, as well as the effect on LH response to exogenous GnRH administered at the time of artificial insemination in nursing rabbits. The effects on fertility and litter size after parturition, as well as litter survival after doe-litter separation, were also examined.

\section{Materials and Methods}

\section{Animals}

Adult, multiparous, lactating, crossbreed rabbits (New Zealand White $\times$ Californian; aged $12-18$ months; $3870 \pm$ $85 \mathrm{~g}$ body weight) $(n=24)$ raised in the Animal Production Department, maintained under controlled light-dark cycles (16 h light: $8 \mathrm{~h}$ dark), and housed in individual metal cages $(32 \mathrm{~cm} \times 52 \mathrm{~cm})$ were used in this study. The rabbits had free access to a commercial diet (Lab Rabbit Chow, Purina Mills Inc. (Torrejón de Ardoz-Madrid): 16.2\% crude protein, 2.5\% fat and $13,5 \%$ crude fibre), and tap water. On day 1 after parturition, the size of the litters was standardized to 8-9 by adding or removing pups.

\section{Experimental design}

This study was performed according to the CEE Council Directive $(86 / 609,1986)$ for the care of experimental animals.

Lactating does were randomly allocated to two groups: control $(n=12)$ or biostimulated $(n=12)$. Control does had free access to nursing, whereas biostimulated does were separated from their litters by a metal screen for $48 \mathrm{~h}$ before artificial insemination (Alvariño et al., 1998; Luzi and Crimella, 1998) from day 9 (at 09:00 h) until day 11 (at 09:00 h) of the lactation period. The nest boxes of biostimulated does were opened at 09:00 h on day 11 of lactation to enable nursing of the litters.

\section{Artificial insemination}

Biostimulated does were artificially inseminated on day 11 of lactation immediately after collection of blood samples and nursing. Control does were inseminated on day 11 of lactation after collection of blood samples. Artificial inseminations were carried out using $1 \mathrm{ml}$ of fresh semen diluted with a commercial extender (MA 24, Ovejero Lab., León,). Each dose contained at least $25 \times 10^{6}$ spermatozoa $\mathrm{ml}^{-1}$. Ovulation was induced by Gonadoreline, a synthetic analogue of GnRH (20 $\mathrm{gg}$ per rabbit i.m.; Ovejero Lab., León), (Alvariño et al., 1998).

\section{Collection of blood samples}

Separation of does from litters was performed at 09:00 $\mathrm{h}$ on day 9 of the lactation period. This was considered as the start point for the collection of blood samples in both groups of does. Blood samples $(3 \mathrm{ml})$ were collected to determine the profile of plasma prolactin, oestradiol and FSH concentrations, as well as plasma $\mathrm{LH}$ pattern release in response to exogenous GnRH administered at the time of artificial insemination. Samples were collected from both groups from the margin ear vein into heparinized tubes, and immediately centrifuged at $1000 \mathrm{~g}$ for $10 \mathrm{~min}$, at $8^{\circ} \mathrm{C}$. Plasma was stored at $-20^{\circ} \mathrm{C}$ until analysed.

Blood samples were collected at intervals of $24 \mathrm{~h}$, from day 9 to day 11 of lactation, to analyse plasma prolactin, oestradiol, FSH and LH concentrations, before artificial insemination and GnRH administration. The first sample on day 11 of lactation was collected before artificial insemination and $\mathrm{GnRH}$ administration (at $0 \mathrm{~h}$ ) in the control group, and just after nursing and before artificial insemination and GnRH administration (at $0 \mathrm{~h}$ ) in the biostimulated group.

For determination of plasma oestradiol, FSH, and LH concentrations after artificial insemination and $\mathrm{GnRH}$ administration, collection of blood samples was performed in both groups $1.0 \mathrm{~h}$ after artificial insemination, and thereafter, at intervals of $30 \mathrm{~min}$ for $4 \mathrm{~h}$, and finally at $7 \mathrm{~h}$ after artificial insemination.

Both groups of does nursed their litters at least $3 \mathrm{~h}$ before collection of blood samples on day 9 for determination of basal plasma concentrations of prolactin. Control rabbits nursed their litters at least $3 \mathrm{~h}$ before collection of blood samples on day 10 and 11 of the lactation. No does of either group nursed their litters after artificial insemination until the last blood sample was collected $7 \mathrm{~h}$ later.

Pregnancies were diagnosed by abdominal palpation on day 12 after insemination. Fertility and litter size was determined after parturition. The effect on litter survival was periodically determined after the doe-litter separation.

\section{Hormone analysis}

Plasma LH, FSH and prolactin concentrations were measured in duplicate samples by specific radioimmunoassay methods, using AFP-3120489, AFP-472176 and AFP-991086 antibodies for LH, FSH and prolactin, respectively, supplied by 
the National Institutes of Health (NIH, Bethesda, MD), and A. F. Parlow (Harbour-UCLA Medical Centre, CA). Hormones were labelled with ${ }^{125} \mathrm{I}$ by the Chloramine-T-method (Greenwood et al., 1963). The antibody titres used were 1:250000 for LH, 1:45000 for FSH and 1:62500 for prolactin assays, respectively. The volume of plasma used was $100 \mu \mathrm{l}$ for $\mathrm{LH}, 75 \mu \mathrm{l}$ for $\mathrm{FSH}$, and $10 \mu \mathrm{l}$ for prolactin determinations. Staphylococcus aureus, prepared by the Universidad Autónoma, Departamento de Fisiología Vegetal (UAM, Madrid), was used to precipitate the bound fraction. The assays were previously validated in our laboratory (Ubilla et al., 1992).

All samples were measured in the same radioimmunoassay to avoid inter-assay variations. The limits of detection for $\mathrm{LH}$, FSH and prolactin were $0.05,0.48$ and $0.125 \mathrm{ng} \mathrm{ml}^{-1}$, respectively. The intra-assay coefficients of variation were $<5 \%$ for LH, FSH and prolactin. Plasma concentrations of oestradiol were determined using a commercial ${ }^{125} \mathrm{I}$ RIA kit (ICN Pharmaceuticals, Inc. Diagnostics Division Costa Mesa, CA, Lot No. E2K9917). Oestradiol concentrations were expressed as $\mathrm{pg} \mathrm{ml}^{-1}$. All samples were analysed in the same assay. The limit of detection was $0.74 \mathrm{pg} \mathrm{ml}^{-1}$, and the intraassay coefficient of variation was $<6 \%$.

\section{Statistical analysis}

All analyses were conducted using the Statistical Analysis System Software for Windows, version 6.12 (SAS Institute Inc., NC). A non-parametric procedure (PROC CATMOD; SAS, 1990) was used to identify significant effects of treatment on the variables that did not present a normal distribution ( $\mathrm{LH}, \mathrm{FSH}$, prolactin, oestradiol concentrations and fertility). The means were compared using the contrast statement. Catmod is a procedure for categorical data modelling. Catmod analyses data that can be represented by a contingency table by fitting linear models to functions of response frequencies and can be used for linear modelling. The contrast statement constructs and tests linear functions of the parameters. One-way analysis of variance (ANOVA) using the general linear models (GLM) procedure of SAS (1990) was used to identify significant effects of treatment on the litter size. This procedure performs analysis of variance for balanced data. The means were compared using Duncan's multiple range test (SAS, 1990). Values were considered significant if $P<0.05$. Data are presented as mean \pm SEM.

\section{Results}

\section{Prolactin}

There were no differences in plasma concentrations of prolactin $48 \mathrm{~h}$ before artificial insemination between the control and biostimulated group. Plasma concentrations of prolactin of biostimulated does were lower $24 \mathrm{~h}$ after doe-litter separation, compared with previous values of the same group, and with control animals $(P<0.05)$. Plasma prolactin concentrations were higher in biostimulated rabbits after nursing compared with those of the control group $(P<0.0001 ;$ Fig. 1$)$.

\section{Oestradiol}

Mean plasma concentrations of oestradiol were similar among control does. There were no differences between the two groups at $48 \mathrm{~h}$ and $24 \mathrm{~h}$ before artificial insemination. The oestradiol concentrations of the biostimulated does were higher than the previous values of the same group from $0 \mathrm{~h}$ to $2.0 \mathrm{~h}$ after artificial insemination $(P<0.001)$. The oestradiol concentrations of the biostimulated group were higher than those of the control group during the following periods: at $0 \mathrm{~h} \quad(P<0.0001), 1.0-2.0 \mathrm{~h}$ after artificial insemination $(P<0.001)$, at $2.5 \mathrm{~h}(P<0.05), 3.0 \mathrm{~h}(P<0.01)$, and $3.5 \mathrm{~h}(P<0.05)$ after artificial insemination. Similar plasma concentrations of oestradiol were observed in both groups from $4 \mathrm{~h}$ to $7 \mathrm{~h}$ after artificial insemination (Fig. 2).

\section{LH}

Plasma LH concentrations of both groups of rabbits were similar in samples collected at $48 \mathrm{~h}, 24 \mathrm{~h}$ and $0 \mathrm{~h}$ before artificial insemination, and at $3-7 \mathrm{~h}$ after artificial insemination. Plasma LH concentrations from $1.0 \mathrm{~h}$ to $2.5 \mathrm{~h}$ after GnRH administered at the time of artificial insemination were higher in both groups compared with the basal values of each group (control: $P<0.0001$; biostimulated $P<0.0005)$. Plasma concentrations of $\mathrm{LH}$ were higher in biostimulated does at $1 \mathrm{~h}$ after exogenous $\mathrm{GnRH}$ and artificial insemination than in control does $(P<0.01)$, and at $1.5-2.5 \mathrm{~h}$ after artificial insemination $(P<0.005)$ compared with the control group (Fig. 3).

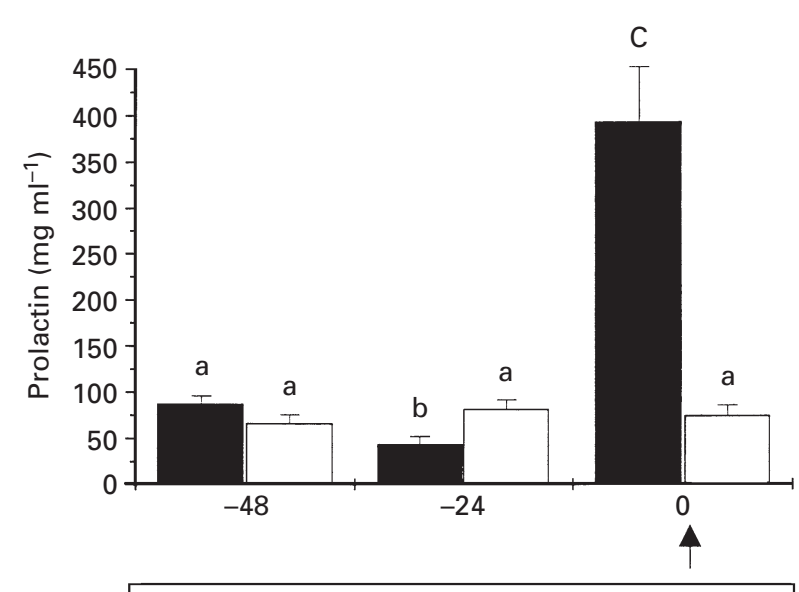

Time (h) before artificial insemination

Fig. 1. Plasma prolactin concentrations in control doe rabbits $(\square)(n=$ $12)$, and in biostimulated doe rabbits $(\square)(n=12)$ before artificial insemination. Biostimulated does nursed their litters before artificial insemination and sampling. The arrow indicates the time of artificial insemination and GnRH administration. The values are means \pm SEM. Significant differences between groups are indicated by different letters: small letters $=(P<0.05)$; capital letters $=(P<0.0001)$. 


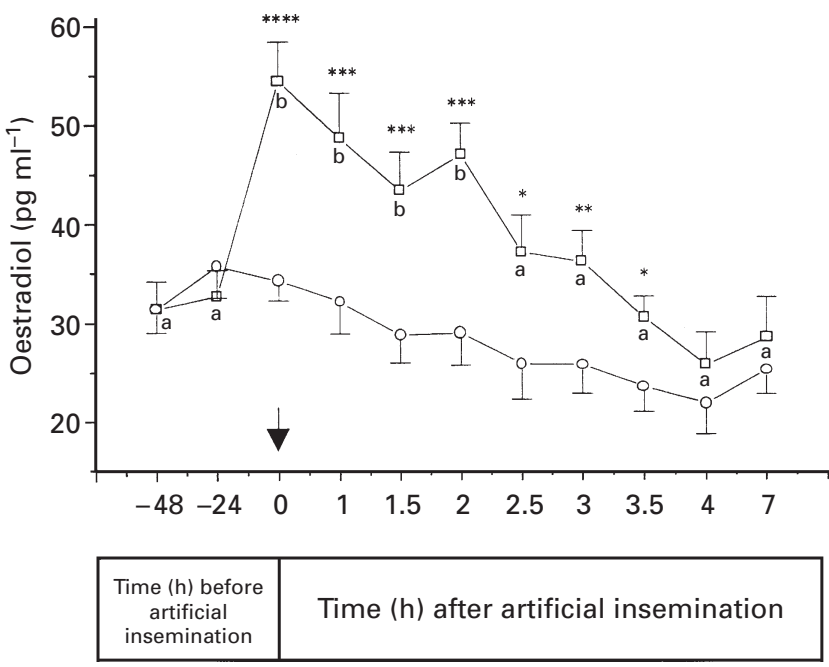

Fig. 2. Plasma oestradiol concentrations in control doe rabbits $(\bigcirc)$ $(n=12)$, and in biostimulated doe rabbits $(\square)(n=12)$. Biostimulated does nursed their litters before artificial insemination and sampling. The arrow indicates the time of artificial insemination and $\mathrm{GnRH}$ administration. Values are means $\pm \mathrm{SEM}$. Asterisks indicate differences between groups: ${ }^{* * *} P<0.0001$; ${ }^{* * *} P<0.001$; ${ }^{* *} P<0.01$; ${ }^{*} P<0.05$. Significant differences compared with basal concentrations are indicated by different letters $(P<0.001)$. Mean plasma oestradiol concentrations were similar among control does.

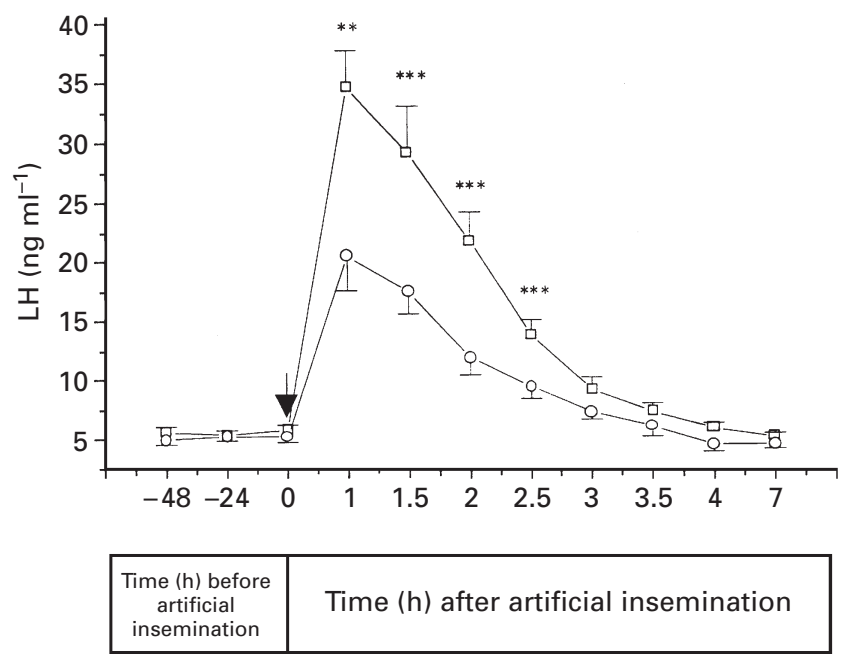

Fig. 3. Plasma LH concentrations in control doe rabbits $(O)(n=12)$ and in biostimulated doe rabbits $(\square)(n=12)$. Biostimulated does nursed their litters before artificial insemination and sampling. The arrow indicates the time of artificial insemination and $\mathrm{GnRH}$ administration. Values are means \pm SEM. Asterisks indicate differences between groups: ${ }^{* * *} P<0.005 ;{ }^{* *} P<0.01$. Control and biostimulated does showed higher concentrations $1 \mathrm{~h}$ to $2.5 \mathrm{~h}$ after artificial insemination compared with the concentrations before artificial insemination for each group $(P<0.0001)$.

\section{FSH}

There were no significant differences in the mean plasma FSH concentrations between the two groups of animals, or among control or biostimulated does $(P<0.1$; Fig. 4$)$.

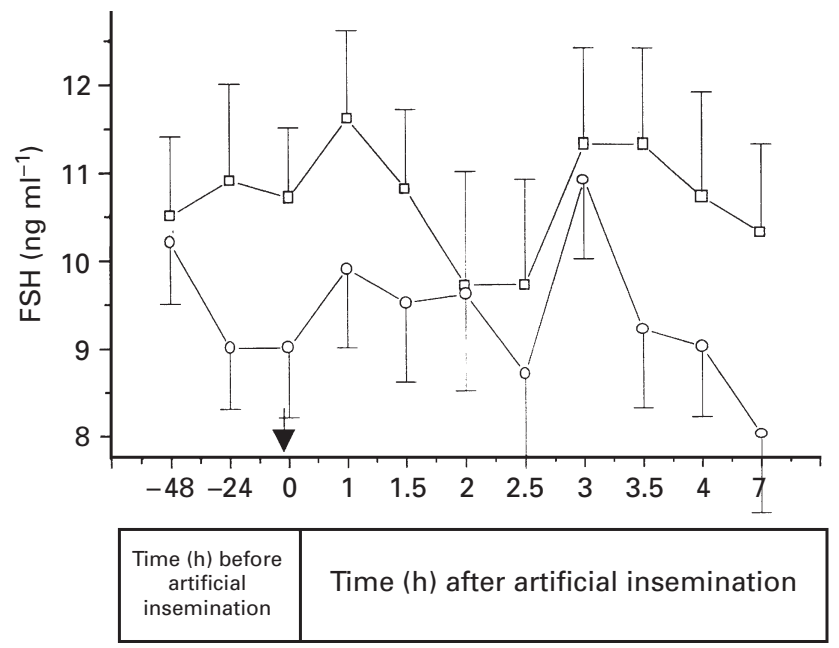

Fig. 4. Plasma FSH concentrations in control doe rabbits $(\bigcirc)(n=12)$ and in biostimulated doe rabbits $(\square)(n=12)$. Biostimulated does nursed their litters before artificial insemination and sampling. The arrow indicates the time of artificial insemination and GnRH administration. Values are means \pm SEM. Biostimulation did not alter plasma FSH concentrations.

\section{Fertility, litter size and litter survival}

No differences were observed in the fertility and litter size between biostimulated and control rabbits $(100 \%$ versus $83.3 \%$, and $9.08 \pm 0.41$ versus $9.2 \pm 0.39$, respectively; $P<0.1$ ). All of the litters survived after the transient doe-litter separation.

\section{Discussion}

The results of the present study indicate that changes in plasma concentrations of oestradiol and prolactin after doe-litter separation and in the pituitary LH response to exogenous GnRH administered at the time of artificial insemination may explain the higher ovarian stimulation and pituitary responsiveness after biostimulation. Plasma concentrations of prolactin measured in control does on days 9, 10 and 11 of lactation, and on day 9 in biostimulated rabbits are in agreement with those observed $2-3 \mathrm{~h}$ after one suckling episode a day during mid-lactation in rabbits (McNeilly and Friesen, 1978; Fuchs et al., 1984), and is characterized by sustained high plasma concentrations of prolactin after suckling, which decline to basal concentrations (Fuchs et al., 1984; Ubilla et al., 1992). Plasma concentrations of prolactin decreased $24 \mathrm{~h}$ after the doe-litter separation, probably as a result of the absence of suckling episodes which stimulate prolactin release (McNeilly and Friesen, 1978). The transitory hypoprolactinaemia found in these does may be implicated in the stimulatory effects on ovarian activity, and sexual receptivity, before artificial insemination. Ubilla et al. (1992) demonstrated that high plasma concentrations of prolactin can inhibit the oestrogenic effect on sexual receptivity during the first week of lactation. Similarly, Theau-Clement et al. (1990) observed that lactation and nursing have a depressive 
effect on sexual behaviour. Hyperprolactinaemia can alter follicular maturation and steroidogenesis in humans (Jacobs et al., 1976; Kauppila et al., 1982), and can inhibit the hypothalamic-pituitary axis, suppressing the gonadotrophin secretion, and follicular development (McNeilly et al., 1982; McNeilly, 1987), not only in rabbits but also in rats (Esquifino et al., 1984). The response to suckling was an increase in prolactin to ten times the basal values measured on day 10 after parturition, and is of similar magnitude to that reported by McNeilly and Friesen (1978) after mechanical stimulation of the nipples. The hypoprolactinaemia together with the increased plasma concentrations of oestradiol found in the present study explain the greater maturation of follicles growing in waves after parturition (Diaz et al.,1987). Indeed, increased follicular steroidogenic activity was observed during the first postpartum day (Osteen and Mills, 1980) and plasma concentrations of oestradiol were high on day 1 and 8 postpartum (Rebollar et al., 1992). Increased oestradiol concentrations were evident $48 \mathrm{~h}$ after separation of the does from their litters, before artificial insemination and $\mathrm{GnRH}$ administration. The concentrations of oestradiol found during this period were comparable with those previously described, and could be related to high follicular activity (Rebollar et al., 1992; Ubilla and Rebollar, 1995).

Administration of GnRH resulted in an LH response in both groups of does. The plasma concentrations of $\mathrm{LH}$ obtained were comparable with those observed by Carlson et al. (1977) and Rebollar et al. (1997). Exogenous GnRH administered at the time of artificial insemination resulted in a greater LH response in does previously separated from their litters for $48 \mathrm{~h}$. This effect could be related to the higher concentrations of oestradiol found in biostimulated does before artificial insemination, enhancing GnRH-stimulated release of LH, as was reported by Huang and Miller (1980). In sheep, oestradiol increases the sensitivity of the pituitary gland to GnRH by stimulating the expression of the GnRH receptor gene that leads to an increased number of $\mathrm{GnRH}$ receptors (Laws et al., 1990; Wu et al., 1994; Turzillo et al., 1994). These effects are probably important when oestradiol concentrations are increased in developing ovarian follicles in the absence of the influence of luteal progesterone (Turzillo et al., 1998). In rabbits, as in other species, the secretion of GnRH by the hypothalamus, and thus LH, appeared to be controlled by ovarian steroids, and also probably by endogenous opioids (Orstead and Spies, 1987). McNeilly (1988) suggested that the inhibition of LH during lactation might be a result of an increased secretion of $\beta$ endorphin produced by suckling in ewes. However, in the present study $\beta$-endorphin should have been decreased, as suckling stimuli were absent in biostimulated animals. There was no luteal influence, as all does kindled 9 days before the beginning of the experiment.

The high concentrations of oestradiol together with the absence of suckling episodes and a transitory hypoprolactinaemia before exogenous GnRH and artificial insemination could have a relevant influence on the LH response of the biostimulated does. Although administration of $\mathrm{GnRH}$ and artificial insemination were performed after suckling, the increased LH response observed indictes that the stimulatory effects of doe-litter separation on the ovaries and pituitary gland could have been produced before the GnRH administration and artificial insemination.

This study failed to show a significant effect of biostimulation on plasma FSH concentrations, probably due to the high variation of the values obtained. Litter size and litter survival were not affected by the doe-litter separation, and were consistent with previous results (Alvariño et al., 1998).

Although no significant differences in fertility were obtained, possibly due to the small number of animals inseminated, the results of this study indicate that the increased breeding efficiency obtained in farm conditions using a large number of lactating does separated from their litters for short periods before artificial insemination (Alvariño et al., 1998; Castellini et al., 1998; Maertens 1998) could result from several stimulatory actions and endocrine changes, probably triggered by transitory hypoprolactinaemia, and the absence of suckling episodes.

In summary, the results of the study reported here indicate that a transient separation of nursing does from their litters before artificial insemination leads to a decrease in plasma concentrations of prolactin that could promote growth of follicular waves, and high steroidogenesis leading to increased plasma concentrations of oestradiol that induce an increased sensitivity of the pituitary gland to exogenous GnRH. These findings, associated with the absence of suckling episodes, and thus, probably low endogenous opioid secretion would lead to a higher LH response and, therefore, exert a major effect on fertility. Additional studies on experimental protocols involving changes in specific hormone concentrations during and after biostimulation would help determine the role of the different hormones on the reproductive performance of doe rabbits.

The authors are grateful to the National Institute of Health $(\mathrm{NIH}$, Bethesda, MD, USA), and A. F. Parlow (Harbour-UCLA Medical Centre, CA, USA), for RIA kits. MINER (Spain), supported this work through the ATYCA Project B0239/97.

\section{References}

Alvariño JMR, Del Arco JA and Bueno A (1998) Effect of mother-litter separation on reproductive performance of lactating rabbit females inseminated on day 4 or 11 post partum World Rabbit Science 6 191-194

Castellini C, Canali C and Boiti C (1998) Effect of mother-litter separation for 24 hours by closing the nestbox or change of cage, on rabbit doe reproduction performance World Rabbit Science 6 199-203

Colin M (1992) Cycle synchronisation in rabbit production Journal of Applied Rabbit Research 15 398-406

Carlson JC, Wong AP and Perrin DG (1977) The effects of prostaglandin and mating on release of $\mathrm{LH}$ in the female rabbit Journal of Reproduction and Fertility 51 87-92

Diaz P, Rodriguez JM, Gosalvez LF and Roman MR (1987) Cyclic ovarian activity in postpartum rabbits Journal of Applied Rabbit Research 10 122-125

Dragan N, Muscalu GR, Seiciu FL, Cocu F, Cimpeanu I, Bunaciu M, Dumitru P, Stefanescu D and Pop T (1996) Effect of prostaglandin analogues on sexual receptivity, fecundity and pregnancy of does $6^{\text {th }}$ World Rabbit Congress 2 65-67

Esquifino AI, Ramos JA and Tresguerres JAF (1984) Possible role of dopamine in changes in $\mathrm{LH}$ and prolactin concentrations after experimentally induced hyperprolactinaemia in rats Journal of Endocrinology $100141-148$

Facchin E, Castellini C, Rasetti G and Ballabio R (1992) L'impiego di 
prostaglandina sistetica (alfaprostol) e di PMSG nella sincronizzacione degli resti e die parti nella coniglia Rivista di Zootecnia Veterinaria 20 11-14

Fortun L and Bolet G (1995) Les effets de la lactation sur les performances de reproduction chez la lapine INRA Production Animals 8 44-56

Fuchs AR, Cubile L, Dawood MY and Jørgensen FS (1984) Release of oxytocin and prolactin by suckling in rabbits throughout lactation Endocrinology 114 462-469

Greenwood FC, Hunter WM and Glover JS (1963) The preparation of ${ }^{131} \mathrm{I}-$ labelled human growth hormone of high specific radioactivity Biochemistry Journal 89 114-123

Huang ES and Miller WL (1980) Effects of estradiol $17-\beta$ on basal and luteinizing hormone releasing hormone-induced secretion of luteinizing hormone and follicle stimulating hormone by ovine pituitary cell culture Biology of Reproduction 23 124-134

Jacobs HS, Frank S, Murragy HAF, Hull MGR, Steel SJ and Nabbao JDN (1976) Clinical and endocrine features of hyperprolactinemia Clinical Endocrinology 5 439-445

Kauppila A, Leinoen P, Vihko R and Ylostalo P (1982) Metoclopramide-induced hyperprolactinemia impairs ovarian follicle maturation and corpus luteum function in women Journal of Clinical Endocrinology and Metabolism 54 955-960

Laws SC, Beggs MJ, Webster JC and Miller WL (1990) Inhibin increases and progesterone decreases receptors for gonadotropin-releasing hormone in ovine pituitary cell culture Endocrinology 127 373-380

Lin KC, Okamura H and Mori (1987) Inhibition of hCG-induced ovulation and steroidogenesis by short-term hyperprolactinemia in female rabbits Edocrinologica Japonica 34 675-683

Luzi F and Crimella C (1998) Effect of change of cage 2 days before artificial insemination on reproductive performance of rabbit does World Rabbit Science 6 195-198

McNeilly AS (1987) Prolactin and the control of gonadotropin secretion Journal of Endocrinology 115 1-5

McNeilly AS (1988) Suckling and the control of gonadotrophin secretion. In The Physiology of Reproduction pp 2323-2349 Eds E Knobil and JD Neill. Raven Press, New York

McNeilly AS and Friesen HG (1978) Prolactin during pregnancy and lactation in the rabbit Endocrinology 102 1548-1554

McNeilly AS, Glasier A, Jonasen J and Howei PW (1982) Evidence for direct inhibition of ovarian function by prolactin Journal of Reproduction and Fertility 65 559-569

Maertens L (1998) Effect of flushing, mother-litter separation and PMSG on the fertility of lactating does and the performance of the litter World Rabbit Science 6 185-190

Mills T and Gerardot RJ (1984) Dissociation of copulation from ovulation in pregnant rabbits Biology of Reproduction 30 1243-1252

Orstead KM and Spies HG (1987) Inhibition of hypothalamic gonadotrophinreleasing hormone release by endogenous opioid peptides in the female rabbit Neuroendocrinology 46 14-23

Osteen KG and Mills TM (1980) Changes in the size, distribution and steroid content of rabbit ovarian follicles during early pseudopregnancy Biology of Reproduction 22 1040-1046
Pavois V, Le Naour J, Ducep O, Perrin G and Duperray J (1994) Une méthode naturelle pour améliorer la receptivité et la fertilité des lapines allaitantes en insémination artificielle. 6émes Journées de la Recherche Cunicole la Rochelle 2 528-535

Pimenta A, Rebollar PG, Alvariño JMR and Alonso R (1996) Induction of rabbit parturition by administration of natural prostaglandin $\mathrm{F}_{2 \alpha} 6^{\text {th }}$ World Rabbit Congress 2 107-110

Rebollar PG, Ubilla E, Alvariño JMR, Illera JC and Silván G (1992) Influencia del nivel de receptividad sexual sobre el estradiol plasmático y la respuesta ovulatoria durante el postparto en la coneja Revista Española de Fisiología 48 13-18

Rebollar PG, Alvariño JMR, Illera JC and Silván G (1997) Effect of gonadoreline and naloxone on induction of ovulation and plasma LH in rabbit Journal of Physiology and Biochemistry 53 205-210

Rodriguez JM and Ubilla E (1988) Effect of sexual receptivity on ovulation response in rabbit does induced with GnRH $4^{\text {th }}$ Congress WRSA Proceedings 504-509

Rodriguez JM, Agrasal C and Esquifino A (1989) Influence of sexual receptivity on LH, FSH and prolactin release after GnRH administration in female rabbits Animal Reproduction Science 20 57-65

SAS (1990) User's Guide, Statistics Statistical Analysis System Institute Inc., Cary NC

Theau-Clément M and Roustan A (1992) A study on relationships between receptivity and lactation in the doe and their influence on reproductive performances Journal of Applied Rabbit Research 15 412-421

Theau-Clément M, Poujardieu L and Bellereaud J (1990) Influence des traitements lumineux, modes de reproduction et états physiologiques sur la productivité de lapines multipares 5èmes Journee Recherce Cunicole France 17

Turzillo AM, Campion CE, Clay CM and Nett TM (1994) Regulation of gonadotropin-releasing hormone $(\mathrm{GnRH})$ receptor messenger ribonucleic acid and $\mathrm{GnRH}$ receptors during the early preovulatory period in the ewe Endocrinology 135 1353-1358

Turzillo AM, Clapper JA, Moss GE and Nett TM (1998) Regulation of ovine GnRH receptor gene expression by progesterone and oestradiol Journal of Reproduction and Fertility 113 251-256

Ubilla E and Rebollar PG (1995) Influence of the postpartum day on plasma oestradiol concentrations, sexual behaviour, and conception rate, in artificially inseminated lactating rabbits Animal Reproduction Science 38 337-344

Ubilla E, Alvariño JMR, Esquifino A and Agrasal C (1992) Effects of induction of parturition by administration of a prostaglandin F2 analogue in rabbits: possible modification of prolactin, LH and FSH secretion patterns Animal Reproduction Science 27 13-20

Yoshimura Y, Maruyama K, Shiraki M, Kawakami S, Fukushima M and Nakamura Y (1990) Prolactin inhibits plasminogen activator activity in the preovulatory follicles Endocrinology 126 631-636

Wu JC, Sealfon SC and Miller WL (1994) Gonadal hormones and gonadotropin-releasing hormone $(\mathrm{GnRH})$ alter messenger ribonucleic acid concentrations for GnRH receptors in sheep Endocrinology 134 1846-1850 